and in the sixth form his interest in goology was awakened by an enlightoned schoolmaster who eneouragod him to read Kelvin and suess. He was thirteen years of age when Rutherford realized that radioactivity might provide a moans for determining the actual ages of minerals, and he was an undergraduate at Imperial College when this idea bore fruit, and Boltwood (using lead ratios) and then Strutt (using helium content) approximately dated a number of uranium-bearing minerals. Working in Strutt's laboratory, Holmes became one of the pioneers in this field, and since that time he has been one of the loaders in applying the results of radioactive methods to the dating of rocks. He took a major part in the construction of a geological timo-scale in terms of millions of years - considering both post- and pre-Cambrian rocks and the age of the Earth itself.

Holmes's major work was not confined to igneous and motamorphic petrology and geological time. His contributions to the geophysical aspects of geology are classic: the nature of orogonic and opeirogenic activity, convection curronts in tho Earth's mantle, continental drift, radioactivity in geology-one could go on for a long time listing the aspects of geology to which he has made major contributions. In fact there is scarcely a main branch of the subject, other than palaeontology, with which his name is not associated. Much of his thinking was on the grand scale, applied to the broad philosophical aspects of the Earth sciences.

Holmes's distinguished career received international acclaim. $\mathrm{H}_{\ominus}$ was elected Corresponding, Foreign or Honorary Member of the Geological Societies of America, Belgium, and Stockholm, and the Academies of Science of the United States, Sweden, the Netherlands, and France. $\mathrm{H}_{\theta}$ was awarded the Murchison and Wollaston Medals of the Geological Society of London, the Penrose Medal of the Geological Society of America, the Fourmarier Modal of the Royal Academy of Belgium, and the MakdougallBrisbane Prize of the Royal Society of Edinburgh. In 1964 he shared with Prof. P. Eskola of Helsinki the Vetlesen, Prize of Columbia University, New York, for outstanding achievement in scionce relating to "a clearer understanding of the Earth, its history or its relation to the universe". $\mathrm{He}$ was a Fellow of the Imperial College of Science and Technology and an Honorary Doctor of Laws of the University of Edinburgh.

In spite of many years of poor health, Holmes continued his creative work until the end. The second edition (largely re-written and greatly enlarged) of his Principles of Physical Geology, published this year, is a masterpiece of lueid writing and shows a breadth of knowledge and vision which few men possess.

Those fortunate enough to have known Prof. Holmes found him a quiot man of oxtraordinary charm and unfailing kindness, and will remember with affoction and gratitude the help and advice which he gave so readily. In 1914 ho marriod Margaret Howe, and they had one son. His wife died in 1938, and he later married Dr. Doris Reynolds, herself a distinguished geologist.

F. H. STEWART

\section{Sir Ernest Thomas Fisk}

WITH the doath of Sir Ernest Thomas Fisk at his horne in Sydney on July 8, at the age of seventy-eight, the world lost a man who made a conspicuous contribution to the development of wireless communication.

Born at Sunbury-on-Thames, England, on August 8, 1886, he entered the Marconi Company's training school in 1906 and came to Australia in 1911 as resident engineer of a branch which the Company had opened in Sydney. $\mathrm{He}$ submitted to the Australian Government proposals for the setting up of a number of wireless stations, but his proposals were not accepted.

In the same year, the Australasian Wireless Company was formed with Australian capital to acquire and operate the patent rights of the Telefunken system. Two years later, Amalgamated Wiroloss (Australasia), Ltd., was inaugurated, and the rights of the Marconi and Telefunken. systems were acquired. Fisk became technical and general manager, and in 1917, managing director.

In Fngland in 1916 Fisk arranged with Marconi to conduct a series of tests, and in the following year he erected an experimental receiving station at Pymble near Sydney. Tests were conducted there with the viow of determining the best type of circuit to use for long-wave, long-distance reception.

Later, Fisk transferred the station to Wahroonga, another Sydney suburb, and began experiments with the Caernarvon station in Wales early in 1918. When the tests were satisfactory, arrangements were made for a public demonstration of direct wireless communication between England and Australia.

Messages to Australian newspapers wero sont from Caernarvon by the then Australian Prime Minister, Mr. W. M. Hughes, and the then Australian Minister for the Navy, Sir Joseph Cook, who were in England at that time. Thoso, the first direct wireless messages between the two countries, were received at Fisk's Wahroonga station and delivered to tho Sydnoy Press.

Later, the experimental receiving station was transferred to Koo-wee-rup, in Victoria, where the scope of the work was extended, new apparatus was installed, and continuous day and night observations made of signals from all high-powered stations in Europe and the United States.

The Koo-wee-rup experimonts established that wiroless waves from England to Australia followed the course of the greatest darkness - a discovery which ultimately was of immense value when aerials for the short-wave sorvice were being designed.

As an outcome of successful experiments, Fisk, on behalf of Amalgamated Wireless in conjunction with the Marconi Company, in 1921 offered to establish a direct wireless servico between Australia, and Groat Britain and to transmit messages at rates one-third less than existing cable charges. The proposal, which was strongly opposed by exponents of a rolay system, found champions in $\mathrm{Mr}$. W. M. Hughes and Genoral Smuts of South Africa. Thoy opposed the relay system and made it clear at the Imperial Conference in 1921 that their respective countries would proceed with direct communication.

Strengthened by the positive attitude of Mr. Hughes, Fisk persisted with his advocacy of a direct service, and in March 1922, on behalf of Amalgamated Wireless, signed an agreement with the Australian Government. under which the Company was to establish and maintain direct wireless communication between Australia and the United Kingdom and Canada, and to assume control of existing coastal and island wireloss stations. The Government acquired 50 per cent of the shares in the Company plus one to give it a bare majority, the remainder of the shares being held by privato shareholders.

Fisk was not daunted by the refusal of the British Government to grant a licence to the Marconi Company to erect a high-power station in England. The experiments were continuod, and in January 1924 tho first transmission. of short-wave signals was received from the Marconi station at Poldhu, Cornwall. In August of that year, a fresh agreomont was entered into with Amalgamated Wireless to erect short-wave transmitters with directional aerials to provide service to Great Britain and to Canada when corresponding stations woro built in those countries. Fisk's foresight and initiative were rewarded in 1927 with the opening of the Boam Service to the United Kingdom, and in 1928 to Canada.

Commenting that the Company had fought against powerful opposition, Royal Commissioners who investigated broadcasting within Australia reported to Federal Parliament in 1927 that the Company, Fisk and his officers were "entitled to great eredit for tho establish- 
ment of the Beam system". They commented that ". . it was largely due to the technical ability and persistence of its managing director that it ultimately prevailed and that Australia has the benefit of an up-to-date and extremely rapid means of communication with Great Britain. . ."

In the field of Australian broadcasting, Fisk was a pioneer. $\mathrm{He}$ gave the first demonstration of wireless telephony in Australia in August 1919. Gramophone music played into a wireless transmitter was received in the lecture room of the Royal Society of New South Wales, several city blocks away. A year later he arranged a complete broadcast concert to a large audience in Parliament House, Melbourne.

He was foundation president of the Institution of Radio Engineers Australia and one of the earliest members of the Wirelsss Institute of Australia. $\mathrm{He}$ continued as chairman of directors of Amalgamated Wireless until 1945.
L. A. Hooke

\section{NEWS and VIEWS}

Royal Society Research Professorship: Prof. W. S. Fyfe

Pror.W. S. FYFE, professor of geology in the University of California, Berkeley, has been appointed to a Royal Society research professorship. He will work at the University of Manchester and will take up his appointment in January 1966. Prof. Fyfe, who was born in New Zealand and has held appointments at the University of Otago and the University of California, is woll known for his work in the field of experimental mineralogy and petrology.

\section{Anglo-French Military Aircraft: Ministry of Aviation: Mr. J. A. Hamilton}

Mr. J. A. Hamilton, formerly of the Royal Aircraft Establishment, Farnborough, has been appointed project director for the Jaguar strike/trainer and the variablegeometry combat aircraft to be developed jointly by the United Kingdom and France. $\mathrm{He}$ will be responsible within the Ministry of Aviation for the management of the two projects, acting in concert with corresponding directors in the French Direction Technique des Constructions Aeronautiques. Mr. Hamilton was educated in Scotland at Penicuik and Lasswade Secondary Schools; he graduated in engineering from the University of Edinburgh in 1943 and then joined the Marine Aircraft Experimental Establishment. He was engaged initially on the development of anti-submarine weapons and later became responsible for all flight research within the Establishment. In 1951 he joined the Aerodynamics Department of the Royal Aircraft Establishment and in 1952 he was appointed head of the Free-flight Division. During his stay at Farnborough he promoted the development of methods for conducting aerodynamic research using rocket-propelled test vehicles, eventually cooperating with the Australian Weapons Research Establishment to extend the technique into the régimes of hypersonic flight. Immediately before transfer to his present post he was head of the Projects Division of the Aerodynamies Department, and in this capacity respons. ible for the preliminary study of future military and civil aircraft.

\section{Special Merit Promotions at the National Physical Laboratory: Mr. H. H. Pearcey}

IT has recently been announced that Mr. H. H. Pearcey, of the Aerodynamics Division, National Physical Laboratory, has had a special merit promotion to deputy chief scientific officer. Mr. Pearcey is an internationally recognized authority in several branches of fluid dynamies, particularly the interaction between shock waves and boundary layers and the many intricate features of transonic, supersonic and separated flows. He has successfully used the results of his research in the progressive development of swept-wing aireraft for eruising at high subsonic, transonic and supersonic speeds by synthesizing methods for the design of the wing section and by evolving advanced section shapes. His 'peaky' type of aerofoil, with isentropic supersonic compressions, and the work that he initiated and supervised on aerofoils with thick trailing edges, including the use of automatic ventilation to reduce the base drag, are well known. So also is his important discovery of the intrinsic connexion between the variation of static pressure at the trailing edge of a wing and the effects of shock-induced and other types of boundary-layer separation. His suggestion that this could be used to predict the threshold of aircraft buffeting has been widely exploited. Mr. Pearcey also made a classic investigation of methods for suppressing the separations that cause the buffeting and other undesirable aerodynamic characteristics. In particular, he demonstrated how the properties of vortex generators can be utilized in this respect and has been instrumental in applying them to numerous aircraft, thus effecting many significant improvements in aerodynamic behaviour and in safety at both high and low speeds. During the course of his work, Mr. Pearcey has made vital contributions to the development of experimental methods for research in high-speed flow and has played a leading part in planning, designing and commissioning the fine range of high-speed windtunnels now operating in the Aerodynamics Division of the National Physical Laboratory. Since 1958 he has been responsible for the High-speed Flow Group at the Laboratory; in 1963 he was awarded the Bronze Medal of the Royal Aeronautical Society, for his contributions to aerodynamics, and gained the Wolfe Award of the Department of Scientific and Industrial Research, for an outstanding contribution to the Department's research programme.

Dr. R. C. Lock

Dr. R. C. Lock, of the Aerodynamics Division, National Physical Laboratory, has been promuted to sonior principal scientific officer (special merit). Dr. Lock is perhaps best known in aviation circles for his outstanding theoretical and experimental research that has produced aerodynamic design methods which render the concept of shock-free, low-drag flow-derived from the abstract infinite yawed wing - a reality for the finite-wing/fuselage combinations of practical aircraft, even for supersonic flight speeds. His papers on this subject are well established and extensively used by aircraft designers; one, on wing planform design, won the Royal Aeronautical Society's Edward Busk Memorial Prize for 1962. Dr. Lock is a leading figure in swept-wing research and plays a prominent part in several programmes in this and related fields that are co-ordinated between the National Physical Laboratory and other establishments in the United Kingdom, Europe and the Commonwealth. However, his reputation is more widely based than this. Already, before joining the Laboratory in 1954, he had had a brilliant career at Cambridge, and this had been interrupted at the end of the War by a brief but successful spell at the Royal Aircraft Establishment working on problems of aireraft design. At Cambridge he won the University Mayhew Prize for the best applied mathematics candidate in the Mathematics Tripos, Part III, and was awarded a research fellowship at Gonville and Caius College during the tenure of which he made important contributions in the fields of hydrodynamic stability and magnetohydrodynamics. At the National Physical Laboratory he first turned his attention to in- 